\title{
СОЦІАЛЬНЕ ОБСЛУГОВУВАННЯ ЛЮДЕЙ ПОХИЛОГО ВІКУ В УМОВАХ ПОШИРЕННЯ SARS-COV-2
}

\begin{abstract}
Анотація. Стаття присвячена соціальній роботі з людьми поважного віку в умовах поширення SARS-CoV-2. Аналіз доступних теоретичних напрацювань у цій галузі дозволив автору статті здійснити комплексне висвітлення напрямів соціальної роботи з людьми поважного віку, що культивуються у практиці українських соціальних служб по роботі з особами похилого віку. Наведене законодавство підкреслює розуміння важливості владою усіх аспектів соціальної роботи з людьми похилого віку. А розробки вчених ілюструють зміст такої роботи. Автор звертає увагу, що найчастіше у професійній діяльності з цієї соціальною групою застосовуеться технологічний підхід, який грунтуеться на вітчизняному досвіді та міжнародних напрацюваннях у цій сфері. Це забезпечуе інтеграцію культур, традицій, сприяе виробленню оптимальних підходів до питань роботи з людьми поважного віку. У роботі коротко описано досвід стаціонарних форм догляду за людьми поважного віку, досвід міжнародного благодійного dронду «Карітас», діяльність освітньої програми «Університет третього віку». Головними технологіями є технологія надання матеріальної допомоги людям поважного віку; технології спілкування; технології проведення психологічної допомоги в тому числі й арт-терапія, яка передбачає підтримання кліента шляхом включення до світу мистецтва, розвиток його талантів, здібностей та обдарувань; освітні технології, які культивуються в університетах третього віку. В умовах поширення інфекції важливо, щоб життя людей поважного віку, які студіювали науку в освітніх закладах не втратило якості. 3 цією метою доцільно розробляти курси, які б могли відвідувати он-лайн. Адже, принцип навчання людини впродовж життя сьогодні не втратив своєї актуальності. Практичною частиною проведеної роботи стало інтерв'ю людей поважного віку. У ході інтервю з'ясовувалися питання, що стосуються проблем людей поважного віку в умовах карантину. В опитуванні взяли участь респонденти Чернівецької області. Відповіді на запитання дозволили визначити такі тенденції: більшість респондентів розраховують на допомогу дітей та родичів у складній життевій ситуації. Проведене опитування засвідчило, що зросла потреба у он-лайн послугах для людей поважного віку, оскільки вони є найбільш вразливою групою населення та актуальною залишається проблема надомної освіти цієї категорії населення. Важливо підготувати майбутніх фрахівців до володіння методиками роботи з людьми поважного віку в умовах карантину. Ці проблеми стануть перспективами для подальших досліджень у цій галузі.
\end{abstract}

Ключові слова: люди похилого віку, освіта дорослих, соціальні служби, соціальна робота 3 людьми похилого віку, поширення SARS-CoV-2.

Kovalchuk Inna

Yuriy Fedkovych Chernivtsi National University

\section{SOCIAL SERVICES FOR THE ELDERLY IN CONDITIONS SARS-COV-2 DISTRIBUTION}

Summary. The article is devoted to social work with people of respectable age in the conditions of spread of SARS-CoV-2. The analysis of available theoretical developments in this field allowed the author of the article to carry out a comprehensive coverage of areas of social work with people of respectable age, cultivated in the practice of Ukrainian social services to work with the elderly. The above legislation emphasizes the government's understanding of the importance of all aspects of social work with the elderly. And the developments of scientists illustrate the content of such work. The author draws attention to the fact that most often in professional activities with this social group a technological approach is used, which is based on domestic experience and international developments in this field. It provides integration of cultures, traditions, promotes development of optimum approaches to questions of work with people of respectable age. The paper briefly describes the experience of inpatient care for the elderly, the experience of the international charity fund "Caritas", the activities of the educational program "University of the Third Age". It is proved that the diversity of work provides coverage of all categories of people of respectable age, contributes to the effective solution of their daily cultural, medical, educational needs. The guiding principles of work with this category of clients should be the principles of humanity, accessibility, integration, competence, optimization. The main technologies are the technology of providing material assistance to people of respectable age; communication technologies; technologies of psychological assistance, including art therapy, which involves supporting the client by including in the world of art, the development of his talents, abilities and talents; educational technologies that are cultivated in universities of the third age. In the context of the spread of the infection, it is important that the lives of people of respectable age who have studied science in educational institutions do not lose quality. To this end, it is advisable to develop courses that could be attended online. After all, the principle of human lifelong learning has not lost its relevance today. Interviewing people of respectable age was a practical part of the work. The interview clarified issues related to the problems of elderly people in quarantine. Respondents from Chernivtsi region took part in the survey. The answers to the questions allowed to identify the following trends: most respondents rely on the help of children and relatives in difficult life situations. Therefore, quarantine brought together old women and their children and grandchildren, relatives. Individual families have been unable to overcome alienation due to prolonged family conflicts. There are old women who rely only on the help of social services, due to forced loneliness or character. Therefore, it seems important to improve the quality and expand the content of social services that work with people of respectable age. It seems expedient to involve volunteers from among the future specialists in this field in such work. People of respectable age prefer to engage in quar- 
antine activities that allow them to stay at home and feel active and needed by the family. The survey showed that the need for online services for the elderly has increased, as they are the most vulnerable group of the population and the problem of home education of this category remains relevant. It is important to prepare future professionals to master the methods of working with people of respectable age in quarantine. These issues will be prospects for further research in this area.

Keywords: elderly people, adult education, social services, social work with elderly people, spread of SARS-CoV-2.

$\Pi$ остановка проблеми зумовлена інтересом міжнародної спільноти до питань старіння людей похилого віку. 3 ініціативи Генеральної Асамблеї ООН 14-го грудня 1990-го року, резолюція № A/RES/45/106, 1 жовтня було визначено Міжнародним днем людей похилого віку. Увага до проблем цієї вікової групи зумовлена не лише даниною традиційної поваги до категорії людей поважного віку, але й стратегічно важливою для усього світу проблемою-зниженням внесків в спеціальний Цільовий фонд з проблем старіння ООН, на тлі стрімкого старіння населення по всьому світу. Поширення SARS-CoV-2 загострило актуальність соціального обслуговування людей поважного віку в аспекті необхідного пошуку нових раціональних способів надання сощіального захисту цій вразливій категорії населення та доцільністю вироблення нових методів і форм догляду й опіки, а також організації навчання цієї вікової групи.

За даними Міністерства соціальної політики, в умовах карантину на Україні більше сорока тисяч сощіальних пращівників і робітників турбуються про добробут громадян похилого віку. Більше тридцяти тисяч соціальних робітників залучені до соціального обслуговування одиноких громадян та осіб з інвалідністю. Соціальна допомога людям похилого віку орієнтована на доставку додому продуктів харчування, медикаментів та інших товарів. Соціальні робітники допомагають сеньйорам сплачувати комунальні рахунки, у приготуванні їжі, у особистому індивідуальному догляді, прибиранні. За рік карантину соціальними працівниками виявлено оріентовно двадцять тисяч осіб похилого віку, що потребують допомоги держави [8].

В умовах карантину чинною залишаеться постанова Кабінету Міністрів України № 256 від 12.04.2017 «Про деякі питання використання коштів державного бюджету для виконання заходів iз соціального захисту дітей, сімей, жінок та інших найбільш вразливих категорій населення». Відповідно до іiі положень громадяни похилого віку мають право на отримання матеріальної допомоги у разі хвороби чи смерті близьких, родичів, чи інших особливих обставин. Програмами соціального захисту передбачена матеріальна допомога сім'ям у складних життевих обставинах: на проведення хірургічних операцій, придбання лікарських засобів, ліквідацію наслідків пожежі, у випадку смерті близьких родичів. Програмою соціального захисту, на муніципальному рівні, охоплено також активістів ветеранського руху. Вони забезпечуються безкоштовними путівками на відпочинок, безкоштовним зубним протезуванням у розмірі дві тисячі двісті гривень.

Станом на перше січня 2020 року в Україні працюе 796 територіальних центрів соціального обслуговування. Сощіальним захистом, що надається цими закладами охоплено близько 1,2 млн. людей похилого віку. Серед них 918 відділень надають допомогу вдома, а 327 відділень проводять свою діяльність на стаціонарній основі. У них проживає біля дванадцяти тисячі осіб; діють 282 будинки-інтернати для осіб похилого віку, осіб з інвалідністю [8]. Отже, законодавча база та статистика роботи соціальних служб переконують у тому, що незважаючи на вимушені складні обставини люди поважного віку забезпечені належним доглядом та турботою з боку держави.

Аналіз останніх публікацій i досліджень. Українську концепцію соціальної роботи з людьми поважного віку сформовано не лише виходячи 3 вітчизняної практики, але й на основі зарубіжного досвіду. Зокрема, основи соціальної геронтології грунтуються на елементах досліджень американських вчених, особливості організащії навчання сеньйорів увібрали кращі зразки досвіду республіки Польща; проведення дозвілля людей поважного віку грунтуеться на вітчизняних традиціях та запозиченнях Німеччини; а у практиці стаціонарних геріатричних закладів вплетено досвід України, Росії, Італії, Швеції. Теоретичні напрацювання Є. Холостової, А. Капської, I. Сагун, I. Трубавіної, Е. Marii $є$ цінним навчальним матеріалом для майбутніх соціальних працівників.

Виділення не вирішених раніше частин проблеми. Хочемо долучитися до існуючих досліджень продовжити тему соціальної допомоги людям похилого віку, але звернути увагу на роботу закладів соціального обслуговування людей похилого віку в умовах поширення вірусу SARS-CoV-2. Оскільки ця проблема є ще актуальною для України.

Метою нашої статті $е$ обгрунтування особливостей соціальної роботи з людьми похилого віку в умовах SARS-CoV-2 і роботи Університетів третього віку, зокрема.

Виклад основного матеріалу. Ми розуміємо соціальну роботу з людьми похилого віку як професійну діяльність, яка здійснюеться спеціально підготовленими фрахівцями та спрямована на надання кваліфікованої допомоги старій людині, ӥi сім’ї або групі осіб похилого віку, які опинилися у скрутному становищі.

Усвідомлюемо, що вона має у структурі: інформування, діагностику, консультування, пряму та фрінансову допомогу, догляд та обслуговування хворих і самотніх людей, які потребують допомоги, та їх орієнтацію на власну активність у вирішенні складних ситуацій.

Перед соціальними працівниками в умовах поширення вірусу SARS-CoV-2 стоїть мета сприяти відновленню здатності людей похилого віку до нормального фрункціонування у суспільстві, забезпечення їм умов для фрізичного виживання, соціальної активності та збереження здоров'я.

З цією метою широко запроваджуються обгрунтовані А. Капською, Є. Холостовою, Ю. Мацкевіч 
технології соціальної роботи, які реалізуються за допомогою техніки спілкування з клієнтами; техніки соціально-організованих дій, які стосуються проживання та оцінки потреб; техніки адаптації, реабілітащії. Особливостями технологій є їх спрямованість на дотримання таких принципів щодо людей похилого віку як: незалежність, участь, догляд, реалізація внутрішнього потенціалу, гідність [9]. Не будемо вдаватися до пояснення суті принципів з огляду на їх відомість фрахівцям. Зазначимо, лише, що хвороба XXI століття загострила соціальний конфлікт співіснування молодого і старого покоління (подібні конфлікти простежувалися на початку XX століття, після Великої вітчизняної війни, і сьогодні, в умовах недостатнього геріатричного фінансування, яке дуже потрібне для надання якісної та вчасної медичної допомоги людям похилого віку). Окремі фрахівці, на жаль, недомагання та хвороби старих людей, розглядають як головну причину бюджетної асиметрії та економічних труднощів геріатрії. Для подолання такого підходу проводяться лекції, відео конференції, круглі столи 3 темою обговорення соціально-корисної активності людей похилого віку.

Провідними принципами соціальної допомоги людям похилого віку, в умовах поширення SARS-CoV-2, залишаються принципи: адресності, гарантованості, диференційованого підходу, самостійності місцевих органів влади і соціального захисту в питаннях організації і проведення заходів щодо надання старим людям соціальної допомоги, соціального регулювання який передбачає перегляд соціальних нормативів у зв'язку з вимогами життя.

Популярними сьогодні $е$ такі різновиди соціального обслуговування літніх сімей та їх членів: обслуговування вдома, яке проводиться у вигляді надання сощіальним працівником побутових та соціально-медичних послуг. Користуються попитом людей поважного віку послуги : доставка продуктів харчування, товарів першої необхідності, медикаментів, різні види особистої допомоги, сплата комунальних послуг, здача білизни до пральні, сприяння у отриманні медичної допомоги, зубного протезування, відвідання підопічних в санітарних лікарняних закладах, сприяння у здійсненні ремонту житла, забезпечення паливом, обробка присадибних ділянок, доставка води, допомога у написанні листів [7, с. 35]. Практикуеться напівстаціонарне обслуговування орієнтоване на медичне, побутове, культурне обслуговування пенсіонерів та інвалідів у денних i нічних стаціонарах, організацію їхнього відпочинку, залучення до посильної трудової діяльності, підтримання звичного способу життя. Має місце термінове соціальне обслуговування, що надається у вигляді невідкладної одноразової допомоги, яка орієнтована на підтримку життедіяльності громадян, котрі негайно потребують соціальної підтримки. Часто це гаряча їжа, забезпечення продуктовими наборами та товарами першої необхідності, надання разової юридичної допомоги, грошової допомоги, спеціального транспорту, засобів санітарії і гігієни.

Соціально-консультативне обслуговування орієнтоване на психологічну підтримку людини похилого віку в умовах поширення вірусу, активізацію i ресурсів для вирішення власних проблем. Практикуеться воно у формі реабілітаційних послуг, тобто таких, які потрібні для критичних ситуацій та, звичайно, стаціонарна dpopма соціального обслуговування яка здійснюеться у центрах соціального обслуговування.

Соціальне обслуговування проводиться на безкоштовній, частково платній і повністю платній основі. Часто до питань оплати лікування людей похилого віку долучаються гуманітарні благодійні фонди, фонд соціального захисту ветеранів Великої вітчизняної війни, товариство Червоного Хреста, релігійні організації.

Серед них на особливу увагу заслуговуе діяльність міжнародного благодійного фонду, що працюе в Україні з 1994 - «Карітас». В умовах, що склалися організація в Україні прагне створити, розвинути та запровадити надійну кваліфіковану модель домашнього догляду. | «Карітас» надає такі послуги, які не в змозі виконати сам хворий, члени його родини чи інші люди, які здійснюють догляд, зокрема: медичне обслуговування і догляд за хворим; реабілітаційні рухові вправи; допомога під час відвідувань лікаря і приватних візитів до хворого; інформація, консультації, емоційна підтримка; прокат допоміжних засобів догляду надання допомоги в домашньому господарстві й організації харчування; навчання догляду та інструктаж членів родини хворого. Працівники «Карітасу» 3 домашнього догляду формують свої завдання у співпраці з членами родини, лікарями, волонтерами [1, с. 34].

В умовах поширення вірусу SARS-CoV-2, доцільно зважати на те, що ціннісні змісти культури створюють передумови відновлення соціальних зв'язків особистості і суспільства, розвиваючи механізми ресоціалізації засобами дозвіллєвих інтересів. Першим, хто визначив компенсаційну суть дозвілля і дозвільневої діяльності, фрункцію суб'єктивної свободи проти вторгнення соціального оточення, був Д. Рісмен. На його думку, вільний час надає зовнішньо детермінованому типу можливість повернутися до самого себе, стає джерелом його індивідуальності й автономізащії. Багато західних дослідників розглядають вільний час як засіб компенсації дійсності. Серед них фрранцузькі теоретики (Ж. Батай, Р. Кейс, В. Райх, Е. Фромм), американські соціологи (Е. Мейо, М. Мід). Однією з особливостей культурної активності людей похилого віку є баланс групової та індивідуальної участі. Хоровий спів, дискусійні клуби, фрізичні вправи, ігри, майстерні за виготовлення предметів народної творчості, освітні курси - такі заходи не тільки підвищують статус людини в її власних очах, задовольняють ïi особисті, культурні потреби, а й підвищують комунікативність, яка надто важлива для людей похилого віку. Участь людей літнього віку у суспільному житті може мати такі форми: політична. Вона виявляеться не лише у голосуванні на виборах, але й участі у політичному житті на місцевому, нащіональному, регіональному рівні. Іншою формою участі у житті суспільства є добровільна волонтерська робота, що охоплює широке коло різних видів діяльності: спорт, культуру, соціальну роботу.

Карантинні заходи, спричинені SARS-CoV-2, зблизили старше і молодше покоління у роди- 
ні. У багатьох дідусів і бабусь налагоджуються дружні взаемини з дітьми та онуками, правнуками. Вони часто відіграють домінуючу роль у мотиваційній сфері людей похилого віку, дають їм відчуття особистісного та сімейного оновлення, вносять різноманіття у їхне життя, надають йому сенсу. Дідусь і бабуся виконують важливі сощіальні ролі, які мають різну мотиваційну спрямованість: присутність - зумовлена прагненням бабусі і дідуся створити спокійну обстановку, особливо за наявності загрози розпаду сім'ї.

Епідемія вплинула на роботу такої соціальної послуги для людей третього віку як «Університети третього віку». Заклади є поширеною формою мобілізації людей старшого віку для задоволення власних потреб. Основне завдання їх діяльності - позбавити людину старшого віку від самотності і надати їй альтернативу у вирішенні власних проблем.

Чернівецький університет третього віку імені Адольфа Кольпінга належить католицькому об'єднанню «Справа Кольпінга», яке супроводжуе та підтримуе людей в житті, вірі, освіті та добрих вчинках. Освіта, діяльність та духовність - це три неписані, тісно між собою поєднані сфери роботи та життя в "Справі Кольпінга".

Соціальна програма призначена для осіб, які вийшли на пенсію і мають потребу в отриманні додаткових знань й умінь. У своїй діяльності університет керується Положенням про Університет третього віку і чинним законодавством України. Серед завдань, яке ставить перед собою заклад основні спрямовані на поліпшення якості життя осіб літнього віку, просвіту, дозвілля, психічне та фізичне відновлення; використання потенціалу людей поважного віку для побудови громадянського суспільства в Україні; захист прав й інтересів слухачів у процесі саморозкриття і розвитку духовних багатств [10].

Для досягнення своєї мети університет реалізуе програми, які спрямовані на примноження історичної і культурної спадщини держави, організацію відпочинку людей поважного віку, спортивні заняття тощо. При цьому за вихідний момент своеї діяльності заклад бере положення про те, що освіта людей літнього віку виступае структурним елементом безперервної освіти та мае власні концептуальні засади, які вимагають врахування характерних психофізіологічних змін особи при оптимально-позитивному старінні [4]. Серед змін уповільнення реакцій при більшій i швидшій стомлюваності, погіршення здатності до сприйняття, звуження обсягу та зменшення тривалості зосередження уваги, труднощі розподілу і переключення уваги, зниження здатності до концентрації уваги, підвищена чутливість до сторонніх перешкод, деяке зменшення можливостей пам'яті, ослаблення тенденції до «автоматичного» запам'ятовування, труднощі відтворення отриманої інформації. Зважаючи на такі особливості в університеті м. Чернівці структурували програму навчання та враховували психолого-педагогічні умови організації процесу навчання людей похилого віку. Так, викладач у своїй діяльності керуеться наступними вимогами: створення позитивної, комфортної атмосфери навчання; врахування досвіду студентів; вияв поваги, толерантності, врахування вікових фізіологічних та психічних порушень слухачів; вивчення потреб та інтересів студентів, та на їх основі розроблення програми й змісту навчання; залучення студентів до розроблення програми навчання та проведення занять (особливо практичного спрямування); постійний моніторинг занять з метою коригування змісту і методів навчання. Освіта людей літнього віку в Університеті третього віку від початку базувалася на навчальних програмах для дорослих, які згодом були модифіковані, шляхом введення специфічних дисциплін для людей похилого віку. У зв'язку з карантином процес відновлення знань здійснюеться в домашніх умовах, організовані індивідуальні консультування в телефонному режимі з питань соціального захисту, соціально-правових питань, щодо отримання комунальних та соціальних послуг. Забезпечено допомогу в організації денної зайнятості, сприяння у відвідуванні бібліотек (з дотриманням вимог карантину) для забезпечення книгами, журналами, газетами.

Карантин вимагае від соціальних працівників та соціальних робітників оперування різноманітними методами і прийомами налагодження та підтримання спілкування 3 людиною похилого віку. Особливостями бесіди 3 людьми похилого віку є побудова їі на принципах довір'я, максимальній природності і невимушеності. Ні в якому випадку вона не має нагадувати спеціальне обстеження, натомість вимагае спеціальних умінь та такту. У ході спілкування 3 людиною похилого віку в умовах обмеженого пересування в межах села чи міста доцільно ясно уявляти ціль; розробити план бесіди; продумати приблизні запитання (важливо щоб одні запитання непомітно перевірялися іншими). Соціальний працівник повинен дати кліенту виговоритися; ні в якому разі не повинен тиснути на клієнта, давати його діям оцінки, засуджувати; бути максимально близьким до мови людини похилого віку, уникати у спілкуванні термінів; при уточненні запитів використовувати ті характеристики, описи, які вживае кліент; бути чітким та лаконічним у висловлюваннях; використовувати прості запитання для розвитку діалогу; мова мае йти про ті задачі і ситуації, які хвилюють кожну людину похилого віку [2]. Головне це бути емпатійним слухачем, який іноді задае коректні запитання, сприяе продовженню бесіди. У бесіді схвалюеться використання техніки парадоксальних запитань, це дозволить виявити протиріччя і побачити справжне відношення людини похилого віку до предмету бесіди. В умовах он-лайн можна практикувати групову дискусію. Ї̈̈ мета - обмін думками і судженнями між членами групи, зняття емоційної напруги, вимушеної самотності. Завдяки дискусії люди поважного віку імпровізують, діють за рамками передбаченого, дослухаються до думки один одного. Цей метод сприяе обміну інформацією, думками на вироблення рішення, досягнення згоди. Саме дискусія сприяе різнобічному обговоренню питання, формуванню всебічного аналізу ситуації. Малоефективною вона буде в питаннях обговорення планів клієнта на майбутне, але цей метод допоможе активізувати потенціал людей похилого віку. 
Для урізноманітнення дозвілля в геріатричних пансіонатах можна проводити рольові ігри за участю до шести осіб. Рольова гра активізуе життеві установки людини похилого віку, дозволить виявити схильність людини похилого віку до виконання певного набору дій в конкретних ситуаціях. Установка виконуе фонкщію стабілізації діяльності, сприяе збереженню ії спрямованості та форми виконання, не дивлячись на зміну ситуації.

Складніше проводити он-лайн особистісноорієнтовану індивідуальні та групову психотерапію, а також різні варіанти аналізу конфліктних переживань кліента. На допомогу у консультуванні прийде арт-терапія. Вона орієнтована на взаємодію арт-терапевта $з$ людьми похилого віку, але при цьому вимагае врахування цілого ряду психологічних, соціальних і фізіологічних факторів. Арт-терапевтичні вправи спрямовані на подолання соціальної ізолящії, підвищення самооцінки людини похилого віку, створення

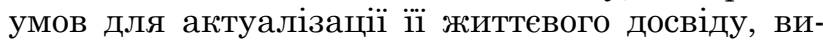
знання цінностей, реалізація нею свого творчого потенціалу. Он-лайн практикуються індивідуальні та групові заняття. Найбільш популярними техніками $е$ техніка "малюнок». Арт-терапевт пропонуе намалювати композицію і передати сусіду по групі. Той домальовуе деталь малюнку і передає далі по колу до тих пір, поки воно не повернеться до свого першого автора. Сприяе знайомству людей похилого віку між собою така арт-терапевтична техніка як "карта життя». Клієнти за поданою схемою, яка включає такі важливі елементи як: сім'я, робота, кар'єра, здоров'я, навчання, мрії використовуючи доступні для них арт-терапевтичні техніки передають важливі моменти їхнього життя, ті, про які вони б хотіли розказати іншим. Потім проводиться групове обговорення особистих карт життя. Важливо щоб клієнти сконцентрували свою увагу на успіхах і досягненнях, колективно обговорили сумніви.

Завдання психологічної допомоги зі зміцнення психічного здоров'я людей похилого віку полягають у: адаптації до статусу пенсіонера, допомозі клієнту розглянути і оцінити свої інтереси та життеві ресурси, обрати для себе захоплюючу справу. У допомозі прийняти старість і все минуле життя у щілому, у пошуку нових оріентирів (формування позитивного образу старості як

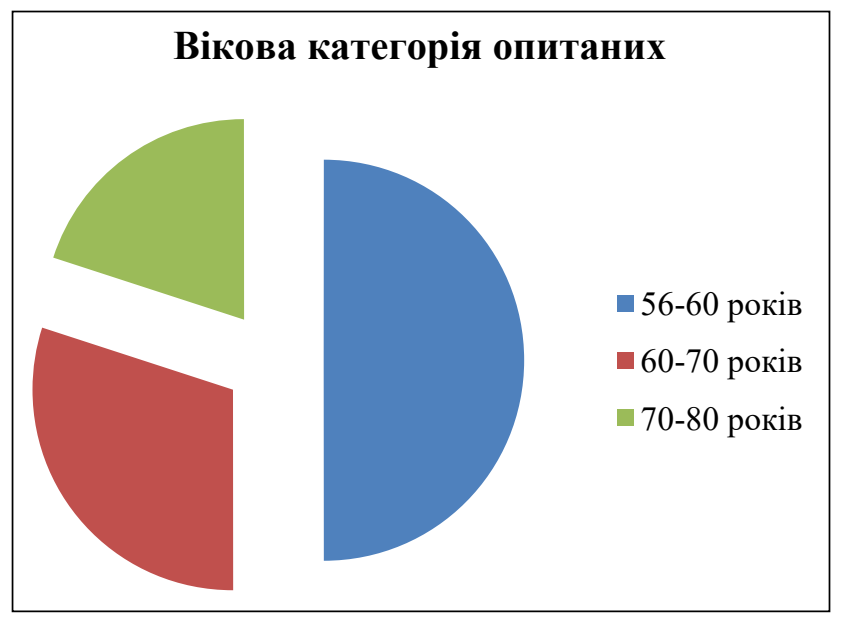

Рис. 1. Вікова категорія опитаних часу для щастя, розвитку, внутрішнього спокою, обговорення всього кращого, що є в актуальній життевій ситуаціі). У підвищенні загального фону настрою. У підтриманні самооцінки.

3 метою оптимізувати роботу з людьми поважного віку в умовах поширення вірусу SARSCoV-2 нами методом інтерв'ю вивчалися потреби цієї вікової групи. В інтерв’ю взяли участь біля 256 осіб віком від 56 до 80 років. Вибірка визначалися випадково. Серед інтерв'юерів особи, які воліють в умовах карантину обмежить спілкування з іншими людьми - 39\%, особи, які ведуть активну волонтерську роботу $-20 \%$, особи, які дотримуються усіх застережних заходів, що культивуються у державі - 41\%. Опитаним задано десять запитань: «Яку поведінку Ви культивуєте в період карантину? Чим зумовлений вибір Вашої поведінки? «Як Ви можете вплинути на ситуацію що склалася стосовно покращення якості життя і благополуччя людей похилого віку? Чи змінилися Ваші сімейні стосунки у період карантину? Чи задоволені Ви якістю медичного обслуговування? Чи користуетеся Ви послугами соціальних працівників (робітників)? Якими саме? Чи задоволені Ви якістю цих послуг? Яка ланка роботи з людьми поважного віку на сьогоднішній день потребуе покращення? У чому?».

Опрацювання результатів дозволило нам зафіксувати та взяти до уваги при підготовці фахівців результати представлені на рисунках:

Вікові категорії опитаних розподілилися таким чином з огляду на два чинники: тривалість життя людей похилого віку та їхню соціальну активність.

Серед опитаних відповідно беруть активну участь у житті країни $10 \%$ осіб у віці до 60 років, і дотримуються усіх карантинних обмежень особи до 70 років. Після 70 років люди поважного віку воліють більше часу проводити вдома. $€$ й такі що до 60 років воліють більше часу проводити вдома, що зумовлено індивідуальними причинами (сімейними зв'язками, емоційними переживаннями людей поважного віку).

У період карантину особи поважного віку займаються більше домашніми справами: читають книги, прибирають у будинку, спілкуються з іншими засобами інтернет ресурсів, відвідують соціальні центри обслуговування людей поважного віку, працюють у групах взаємодопомоги.

Графічно результати зображено на рисунку 3 .

Отже, показник відвідування центрів соціальних служб, які надають послуги людям похилого віку зменшився, що свідчить про необхідність тимчасового зміщення акцентів в роботі з цією категорією населення на домашне обслуговування та надання інформаційної освіти.

Більшість опитаних 70\% аргументують вибір поведінки страхом захворіти на вірус і через це понести матеріальні збитки (45\%) та померти (55\%). Більшість опитаних передбачають летальний вихід 3 хвороби через ослаблений організм, незбалансоване харчування, низький рівень матеріального достатку. Ці відповіді вимагають взяття їх на озброення практичними психологами, що працюють у соціальних службах, а також відділам матеріального забезпечення людей похилого віку для того, щоб оптимізувати роботу у цьому напрямі. Більше половини опитаних (75\%) вважають, що можуть позитивно вплинути 


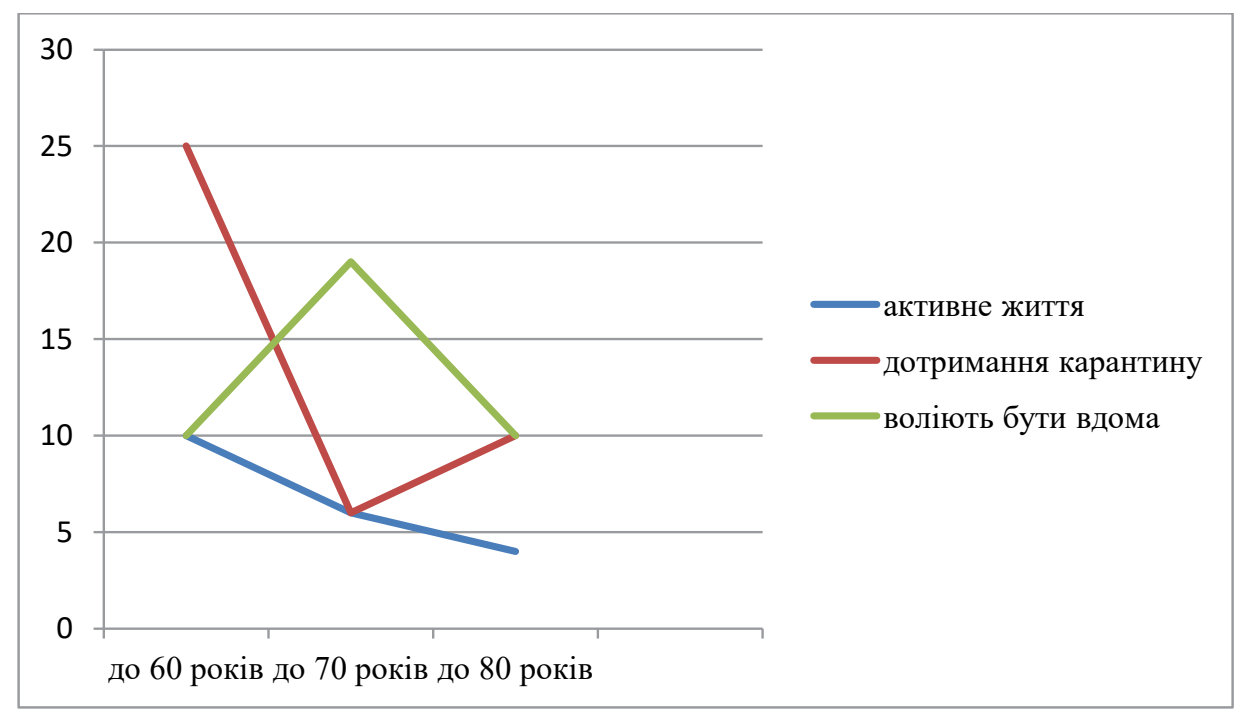

Рис. 2. Результати інтерв'ю щодо вибору способу поведінки в умовах поширення вірусу

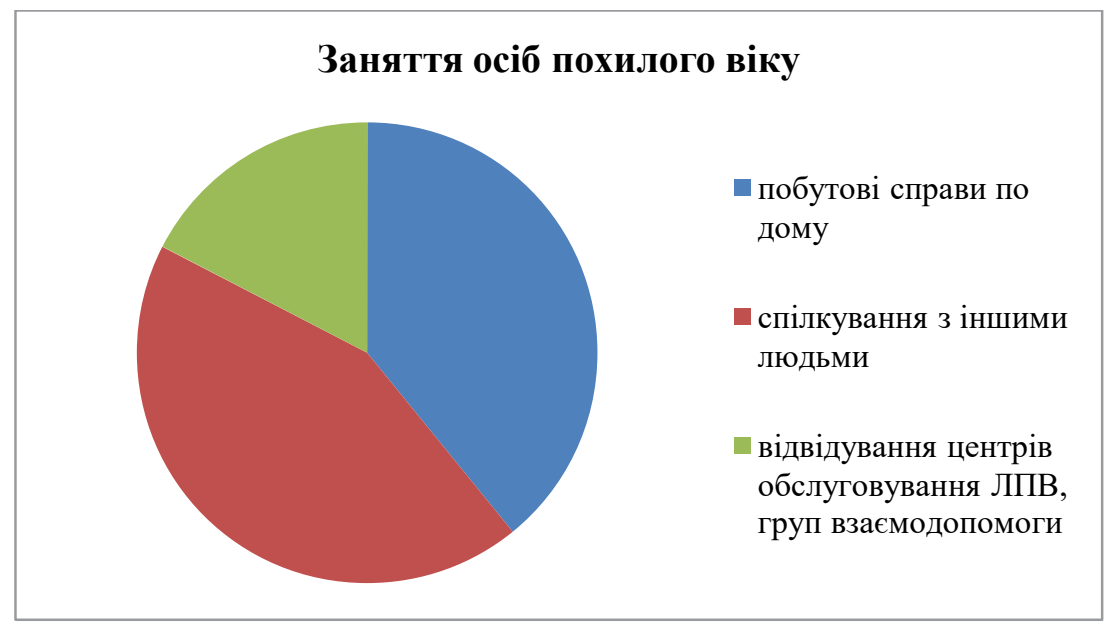

Рис. 3. Провідні заняття осіб поважного віку

на ситуацію коли в таких умовах обмежать коло безпосереднього спілкування і перейдуть на онлайн спілкування чи на телефронне. $5 \%$ опитаних вважають, що маючи медичну освіту зможуть допомогти у профрілактиці поширення вірусу, а ще $20 \%$ уникнули відповіді.

Сімейні стосунки у опитаних змінилися у позитивний бік. Вони частіше стали бачитися $з$ ді- тьми та онуками, що проживали окремо - 65\%, так як ті приносять їжу і ліки. У 10\% ніяких змін не відбулося, оскільки вони повністю на державному утриманні; а 20\% відзначили, що змін у сімейних стосунках не відбулося через давні конфрлікти 3 дітьми; у 5\% сімейні взаємини погіршилися через смерть близьких людей.

Графрічно це ілюструє рисунок 4.

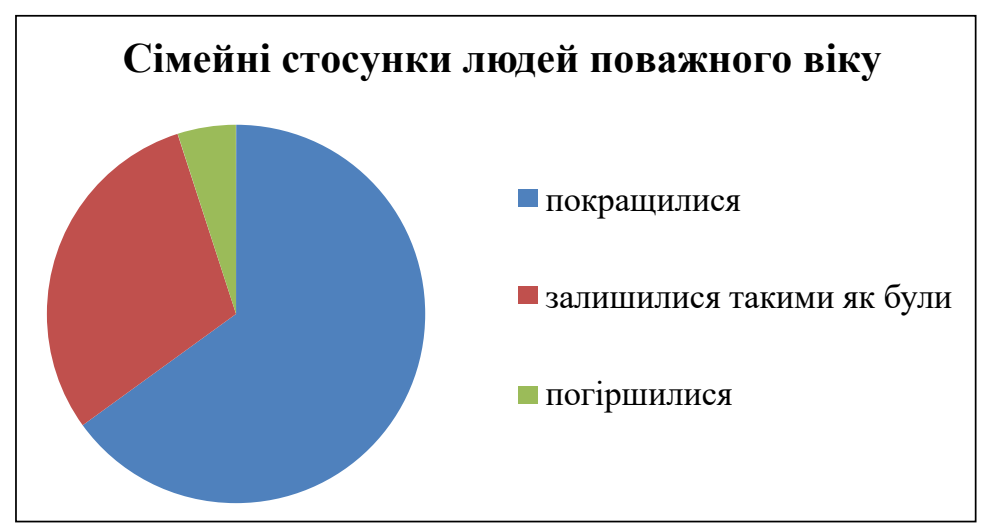

Рис. 4. Сімейні стосунки людей поважного віку 
Медичними послугами скористалися більше половини опитаних, в основному: в віці до 60 років (35\%) і в віці $60-70$ років (25\%), у віці до 80 років (15\%). Не зверталися до послуг медичних закладів 25\% опитаних. Соціальним послугами скористалися менше половини опитаних - 45\%. В основному це надання консультацій щодо пенсійного забезпечення і субсидій.

Люди поважного віку вважають, що найбільш актуальними сьогодні у соціальній роботі з ними e проведення он-лайн навчання щодо користування сучасними інформаційними технологіями, он-лайн консультації щодо соціального захисту та створення банку доступних соціальних послуг як на безоплатній так і на платній основі, надання оперативної психологічної допомоги у стресі.

Проведене дослідження вимагае більш масштабної вибірки. Але й отримані нами показники дозволяють говорити про доцільність формування актуальних на сьогодні напрямів роботи з людьми поважного віку: профрілактики поширення інфекції серед осіб поважного віку, створення банку послуг, надання якісної он-лайн освіти, створення розважальних сімейних програм, проведення психологічного консультування, озброення майбутніх соціальних працівників методиками роботи з людьми поважного віку в умовах поширення вірусних інфекцій, перенавчання існуючого персоналу щодо роботи в нових умовах (користування найпростішими медичними апаратами, техніками спілкування з людьми поважного віку в стресових ситуаціях). Вважаємо, що ці заходи дозволять особам поважного віку краще соціалізуватися в умовах поширення вірусу, та сприятимуть подоланню ними стану безпорадності та сезонної депресії.

Висновки і пропозиції. Узагальнення результатів дозволяе сформулювати висновки про те, що добре організована, цілеспрямована робота з людьми поважного віку, в умовах поширення вірусної інфекції, забезпечить позитивні результати за умов: проведення профілактичної роботи серед осіб цієї категорії. До ціеї роботи мають залучатися волонтери, студенти спеціальності «Соціальна робота", викладачі вищих навчальних закладів, працівники геріатричних закладів. Наступною не менш цінною умовою $е$ навчання самих людей поважного віку правилам користування інформаційними технологіями: Інтернетом, телефоном, а також правилам дотримання особистої гігієни. Важливим видається в умовах, які склалися, відпрацьована відповідно до існуючого державного та міжнародного законодавства робота соціальних служб, які забезпечують соці- альний захист людей поважного віку. Доцільно до такої роботи залучати місцеві мас-медіа. Найбільш актуальною на сьогодні видається робота з сім'єю людини поважного віку в напрямі профрілактики сімейних конфліктів, адже, як показало опитування саме найближче оточення люди поважного віку розглядають як головне джерело допомоги, тому доброзичливі взаємини є могутнім стимулом для самоорганізації особистості. 3 цією метою можна проводити он-лайн консультації, навчання людей похилого віку, психологічні консультування на телефоні довіри. Потребують доопрацювання питання фахової підготовки фахівців до роботи з людьми поважного віку в умовах поширення вірусної інфекції. Вважаемо, що провідними принципами у цьому питанні мають стати принципи: гуманності, що передбачають гуманний підхід до людей поважного віку при наданні їм соціальних послуг та гуманні основи фохової підготовки спеціалістів до такої роботи. Принцип інтегрованості, який оріентуе на співпрацю державних, приватних ініціатив на цьому полі роботи. Принцип науковості, який передбачає використання у такій роботі науково виважених фактів та даних. Принцип оптимізації, який дозволяе досягати поставлених завдань у роботі з людьми поважного віку за найменших затрат часу і ресурсів. I безперечно не можливо оминути увагою принцип доступності наданих послуг. Доступність передбачає створення матеріально доступних послуг для людей поважного віку та забезпечення доступного життевого простору для ціеї категорії осіб що дозволяло б їм безперешкодно дістатися до соціальних центрів, які здійснюють соціальний захист людей поважного віку. Принцип компетентності мае передбачати запровадження різнопланових заходів, які сприяють формуванню знань, умінь та навичок роботи з людьми поважного віку, враховуючи їх життевий досвід та знання.

Розпочате дослідження має перспективи, які полягають у запровадженні у освітній процес навчальних закладів, які здійснюють підготовку соціальних працівників до роботи з людьми поважного віку навчального матеріалу, що забезпечив би знання про заходи, які можна впроваджувати у роботу з людьми поважного віку в умовах поширення вірусних інфекщій, уміння та навички злагодженої інтегрованої взаємодії усіх фахівців, які працюють з людьми поважного віку. Не можна залишати без уваги розпочате опитування. Залучення до опитування більшої кількості респондентів дозволить правильно визначити вектори актуальної соціальної роботи у цьому напрямі.

\section{Список літератури:}

1. Бойко А.М., Боднаренко Н.Б. Соціальна робота. Робота з конкретними групами кліентів. Київ : Киево-Могилянська академія, 2004. 166 с.

2. Вельвовский И.З., Лигигарт Н.К., Багалей Е.М., Сухоруков В.И. Психотерапия в клинической практике. Київ : Здоров'я, 1984. 160 с.

3. Принципы Организации Объединенных Наций в отношении пожилых людей. URL: https://zakon.rada.gov.ua/ (дата звернення: 20.01.2021).

4. Сагун I. Міжнародний досвід організації навчання людей третього віку. Освіта дорослих. 2010. Вип. 2. C. 199-208.

5. Капська А.Й. Соціальна робота : навчальний посібник. Київ : Центр навчальної літератури, 2005. 328 с.

6. Мацкевич Ю.Р. Підготовка соціальних педагогів до роботи з людьми похилого віку: визначення проблеми. Наукові записки Ніжинського держ. пед. ун-ту іл. М. Гоголя. Сер. Психолого-педагогічні науки. 2001. С. 37-41.

7. Ковальчук I.В., Филипчук В.С. Методика соціально-педагогічної роботи з людьми похилого віку. Чернівці : ЧНУ, 2009. $184 \mathrm{c}$. 
8. Міністерство соціальної політики Близько 40 тисяч працівників соціальних служб надають необхідні послуги людям, які потребують допомоги. URL: https://www.msp.gov.ua (дата звернення: 20.01.2021).

9. Статут університету третього віку імені Адольра Кольпінга. Життя i знання. 2016. С. 23.

10. Холостова Е.И. Социальная работа с пожилыми людьми : учебное пособие. Москва : Дашков и К., 2003.296 с.

11. Maria E. Zuniga. Aging: Social Work Practice. Encyclopedia of Social Work. XIX edition. England : Oxford University Press, 2008.

\section{References:}

1. Boiko A.M., Bodnarenko N. B. (2004) Sotsialna robota. Robota z konkretnymy hrupamy kliientiv. Kyiv: KyievoMohylianska akademiia.

2. Vel'vovskij I.Z., Ligigart N.K., Bagalej E.M., Suhorukov V.I. (1984) Psihoterapiya v klinicheskoj praktike. Kyiv: Zdorov'e. (in Russian)

3. Printsipy Organizatsii Obedinennykh Natsiy v otnoshenii pozhilykh lyudey. Available at: https://zakon.rada.gov.ua/ (accessed 20 January 2021).

4. Sahun I. (2010) Mizhnarodnyi dosvid orhanizatsii navchannia liudei tretoho viku. Osvita doroslykh, vol. 2, pp. $199-208$.

5. Kapska A.Y. (2005) Sotsialna robota: navchalnyi posibnyk. Kyiv: Tsentr navchalnoi literatury.

6. Matskevych Yu.R. (2001) Pidhotovka sotsialnykh pedahohiv do roboty z liudmy pokhyloho viku: vyznachennia problemy. Naukovi zapysky Nizhynskoho derzh. ped. un-tu im. M. Hoholia. Ser. Psykholoho-pedahohichni nauky, pp. 37-41.

7. Kovalchuk I.V., Fylypchuk V.S. (2009) Metodyka sotsialno-pedahohichnoi roboty z liudmy pokhyloho viku. Chernivtsi: ChNU.

8. Ministerstvo sotsialnoi polityky. Blyzko 40 tysiach pratsivnykiv sotsialnykh sluzhb nadaiut neobkhidni posluhy liudiam, yaki potrebuiut dopomohy. Available at: https://www.msp.gov.ua. (accessed 20 January 2021).

9. Statut universytetu tretoho viku imeni Adolfa Kolpinha (2016). Zhyttia i znannia, p. 23.

10. Holostova E.I. (2003) Social'naya rabota s pozhilymi lyud'mi: uchebnoe posobie. Moscow: Dashkov i K.

11. Maria E. Zuniga (2008) Aging: Social Work Practice. Encyclopedia of Social Work. XIX edition. England: Oxford University Press. 